\title{
Two New Arabic Editions: A Land Survey from Ihnās and Ḥadīths Concerning Funerary Practice
}

\author{
Alia Hanafi
}

This article provides editions of two unrelated documents, one paper, the other papyrus, which were never studied previously. The first text is in fact a small codex consisting of two folded sheets of paper resulting in eight pages of text. It records the land holdings in the estate ( day $^{c} a$ ) of Drinja in the pagarchy Ihnās as measured in the survey of the year 383/993-994. A nice example of medieval record keeping, it can be used to examine administrative practice, preservation and archiving. Although publicly taxed kharāj land is mentioned in the text, there are also suggestions that it refers to a more privately managed or tax-farming context. Close examination could result in a better understanding of the relation between privately and publically held property, disentangling the often difficult to distinguish categories of farmed out, rented, managed or owned land.

The second text contains hadīths concerning funerary practice. Funerary practices have been vehemently discussed in Islam from its earliest history up to the modern period. ${ }^{1}$ Typically these rituals with their strong (local) traditions and customs are measured against Muslim tradition and practice. ${ }^{2}$ Bearing strong associations and intense emotions for believers they are a powerful tool in Islamic identity formation. Whether this papyrus fragment should be interpreted as taking part in this debate or simply as the part of the chapter on funerary practices in a regular hadith collection cannot be determined at this point. It is written on an early papyrus and records some known and unknown traditions with the chains of transmitters going back to the prophet Muhammad or his companions. Most of the traditions are well-known although the papyrus contains some variants in the text and in the isnāds.

1 For the medieval period, see for example Halevi, Muhammad's. For current debates, see for example Becker, Islamic (Africa), Federspiel, Persatuan (Indonesia) and Abashin, The logic (Central Asia). See also Anne Regourd's article in this volume.

2 Halevi, Muhammad's; Smith and Haddad, The Islamic.

(c) ALIA HANAFI, 2015 | DOI:10.1163/9789004284340_015

This is an open access chapter distributed under the terms of the prevailing CC-BY-NC License at the time of publication. 
P. Haun. Inv. Arab. 21; 22 Provenance Ihnās (left outlined) figs. 14.1-14.4

No. $21(30.9 \times 17.2 \mathrm{~cm}) \quad$.383 AH $(26$ Feb. $993-17$ Jan. 994C.E. $)$

No. $22(30.9 \times 21.1 \mathrm{~cm}$. $)$

The two sheets of paper are brown and strong. They are each folded in half and written on both sides, forming eight pages of text. Sheet no. 22 is complete and measures $30.9 \mathrm{~cm}$. (width) by $21.1 \mathrm{~cm}$ (length). No. 21 measures $30.9 \mathrm{~cm}$. by $17.2 \mathrm{~cm}$., so a stroke of $3.9 \mathrm{~cm}$ is missing at the bottom. There are large and small holes in the middle part of the sheets.

The handwriting in black ink is a clerical and skilled hand. Dacritical points are lacking. Since the ink had not completely dried before the scribe turned the page, a slight copy of the letters appears on the facing pages. Accordingly, it seems that although these sheets were part of a notebook they were not quired. ${ }^{3}$ We do, however, undoubtedly have successive leaves, with each sheet folded vertically down the middle producing conjoint leaves. The scribe started his writing on the outer page of the left-hand leaf of the first sheet, then continued on the inner page of the same leaf, first filling the right side then the left side of the page, moving to the right side of the outer page of the first leaf (all inv. Arab 21). He then moved to the outer page of the second leaf, where he started on the left side of the page repeating the same pattern as before ending on the right side of the outer page (all inv. Arab 22).

Page 1 is clearly the beginning of the book, as the title of the account appears on it, with pages 4, 5, 6 and 7 containing the bulk of the text. Page 8 seems to be the end of the document.

The document is a report of a surveyor concerning an estate called Drinja (درنجه) in the pagarchy of Ihnās (Heracleopolite) and deals with the annual assessment of taxes. It is dated 383 AH (26 February 993-17 January 994), during the rule of the Fāṭimid caliph Abū Manșūr Nizār al-'Azīz bi-llāh (r. 975-996). Different agricultural products are mentioned such as ordīnāry flax (kattān) (p. 4, ll. 1, 5, and p. 5, ll. 1, 2) and flax of high quality (p. 3, l. 6), grapes, lotus fruit (both p. 7, l. 5), figs (p. 2, l. 6), pulse (qațānī), barley (sha ìr), trefolium, cartamus (safflower) (all four p. 4, l. 3) folium and calamus aromaticus (both p. 5, l. 1).

Two major features may be noted in the structure of our document providing insights into agricultural record keeping. The real aggregate survey of the land of the whole day'a of Drinja is registered first, followed by the actual measure

3 For the structure of a codex, see Casson and Hettich, Excavation 3. 
of farmed land. At the end of the document different payments are recorded in the names of different individuals (p. 8). In Egypt, the survey made at the time of the seasonal decrease of the Nile flood recorded not only the actual area of land involved but also the amount of work needed considering the degree of natural irrigation by the flood. On the basis of these two factors the amount of taxation that could be expected to be raised was calculated. At later stages the taxes due were adjusted based on the actual land worked and the measure in which crops grew. ${ }^{4}$ Notary practice can also be observed in the text. In the margin, next to some of the lines the balance of the estimated assessment is written (e.g. p. 3, l. الموقف 3 (الم) The scribe used some abbreviations such as the letter nün for niṣf (half) and فدانا المدان

P. Haun. Inv. Arab. $27^{5}$

Page 1 (Fig. 14.1, left side)

$$
\text { لله المحد والمنة }
$$

$$
12
$$

Page 2 (Fig. 14.2, right side)

$$
\begin{aligned}
& 1 \\
& \text { 2 } 2 \\
& 3 \\
& 4
\end{aligned}
$$

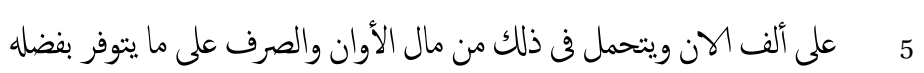

$$
\begin{aligned}
& 6 \\
& 7 \\
& 8 \\
& 9
\end{aligned}
$$

4 For this system, see the description by al-Makhzūmī (d. 585/1189), Kitāb Minhāj 58-63 (cited in P.Khalili I, pp. 61ff.); Frantz-Murphy, The agrarian 20-26.

5 In the edition hamza is added according to the rules of standard Arabic orthography. 
Page 3 (Fig. 14.2, left side)

$$
\begin{aligned}
& 1 \\
& 2 \\
& \text { ألف تسعة وسبعين فدا(نا) } \\
& \text { وربع وسدس } \\
& \text { وثثلين وثمن } \\
& 3 \\
& \text { اربع مائة وستة دينار } \\
& 4 \\
& \text { عن مائتى واحد وسبعين فدانا ونصف ونصف ونص[ف] } \\
& \text { اربع مائة وخس دينار } \\
& \text { عن تمن مائة وثلاث وثلا [ثين ] } \\
& \text { ثمن } \\
& \text { عن مائتى وسبعين فدانا كتان ونصفا وربع } \\
& \text { الفدان } \\
& \text { دينـار واحد } \\
& \text { ـ } 6 \\
& \text { ونصف ونصفمن } \\
& \text { عن فدان ونصف ونصفمن كتان عالى }
\end{aligned}
$$

Page 4 (Fig. 14.1, right side)

$$
\text { ثلثمية وتس][ــ]ة ف[ـدا(نا)] }
$$$$
\text { عن مائة وسبعة عشر فدانا ونصف وثمن }
$$$$
\text { كتان ثلث الفدان }
$$

خمس عشر فدا(نا)

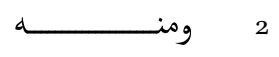

$$
\text { [ وسدس عنس }
$$$$
\text { عن سبعة وعشرين و [ثَّ]ن و [نصف ثم]ن }
$$

الفدان

] مائتى وتسعة ونصف فدا (نا )

$$
3
$$

وثلث وربع وسدس وسمه ونصن عن أربع مائة وأربعة وأربعين ونصف وركيع ولترطم

مائتى واحد [وعشري]]ن فدا(نا) عن ثلثية وتسعة وثمنين فدانا وثن

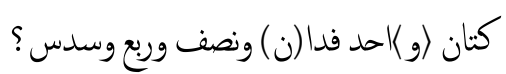




\section{P. Haun. Inv. Arab. 22}

Page 5 (Fig. 14.3, left side)

$$
\begin{aligned}
& 1
\end{aligned}
$$

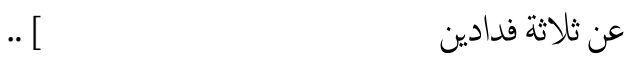

$$
\begin{aligned}
& \text { تسعة دينار } \\
& \text { [ } \\
& \text { عن فدانين وربع وسدس وسدس ثمن كتان نصف وسدس ونصف خمس لـ } \\
& \text { الفدان } \\
& \text { دينار واحد } \\
& 3 \\
& \text { وخس } \\
& \text { عن نصف ونصفتمن } \\
& \text { ثلثمائة وتسعة وألف فدا (نا) } \\
& 4 \\
& \text { ونصف وخمس }
\end{aligned}
$$

Page 6 (Fig. 14.4, right side)

$$
\begin{aligned}
& \text { ] مائة وتسعة وتمنين فدا(نا) } \\
& 1 \\
& \text { وثلث وخمس } \\
& \text { [أربعين فدا (نا ) الساحل أربعة عثر فدا (نا) } \\
& \text { [الـ } 2 \\
& \text { الخـــــر مائة وعشر فدا(نا) } \\
& \text { مائة ودينارن } \\
& 3
\end{aligned}
$$

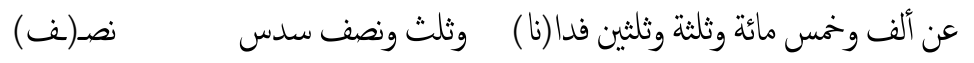

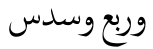

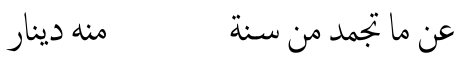

$$
\begin{aligned}
& \text { دينــــار } \\
& 4 \\
& \text { ون (صف ) } \\
& \text { ونصف وربع }
\end{aligned}
$$

Page 7 (Fig. 14.4, left side)

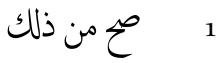

$$
\begin{aligned}
& 2
\end{aligned}
$$

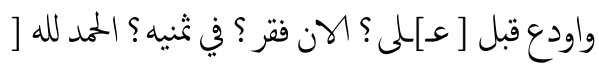




$$
3
$$

برمهات مائة وستة وخمسين فدا (نا ) وسد]س]
4 بابه وأمشير تسعة وذ(صف) فدا(نا)

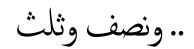

لعنب ونبق ثلثماية وتسعة ع[شر ] فدا (نا)

5

$$
\text { وذ(صف) وثلث وربع }
$$$$
\text { ون(صف) }
$$

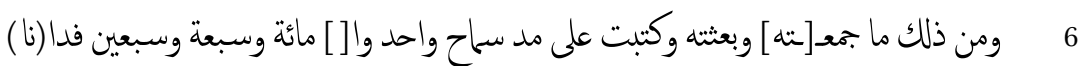
وثلث وربع وسدسثمن

$$
\begin{aligned}
& \text { الصالح ستم[اية و]سبـ [ ].. } \\
& 7 \\
& \text {.. [ } \\
& \text { ] ونصف وربع } \\
& 8
\end{aligned}
$$

Page 8 (Fig. 14.3, right side)

مائة دينار

2 $\quad 2$

4 وثلثين

سبعين فدا(نا)

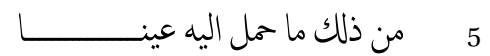

$$
\text { وربع وسدس }
$$

اربعة وثلثين فدا (نا)

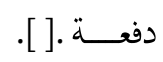

تسعة عشر فدا(نا)

6

$$
\begin{aligned}
& \text { قيد الوكيل؟ ونصف وثلث } \\
& \text { عن خمسة وثلثين [فدا (نا) } \\
& \text { دفع[-[]ة } \\
& \text { عن تسع ] }
\end{aligned}
$$

$$
\text { عن عشرين فدا(نا) وثلث وربع }
$$

أحد عشر فدا(نا)

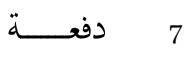

$$
\text { عن اثنى عثر }
$$

8

$$
9
$$




\section{Translation}

Page 1

1 The result of the survey of the domain known as Drinja.

$2 \quad$ For the year three hundred and eighty three. (vac.) To Him comes praise and He is generous.

\section{Page 2}

1 In the name of God, the Compassionate, the Merciful.

2 Amount of what resulted from the contracts of the domain known as Drinja of the district of Ihnās.

3 For the year three hundred and eighty three on what was aggregated of the gross from the survey of (the domain of) Ishạa, originating from Bā $[\mathrm{d}]$ is? and? ....

4 to which [are added] the prices of the materials, and Abū Rā[ḍî?] should be charged for that from the circulated money

5 on one thousand now and he will pay in that (case) from the current money and expenses on what is saved from its growth (or increase).

6 So, the rest is what will be expected from growing some figs (trees) and what is collected from the flax (kattān) of the cultivation of the estate.

7 ] to collect a sum from Habīqa. It is one hundred, which should be added to

8 ] one hundred and sixty dīnärs

9 ] and a half and one third and one sixth

$10 \quad]$.

\section{Page 3}

1 (vac.) There from (vac.)

$2 \quad k h a r a \bar{j}$ land [ ] one thousand four hundred sixty nine faddāns and a quarter and one sixth.

3 The situation (is) eight hundred and [thirty] three ... (from) one thousand and seventy nine faddāns and two thirds and one eighth.

4 The wheat: from two hundred seventy one faddāns and a half and one half of an eighth (comes) four hundred and six dinārs, and a half and one half of an eighth.

5 Thereof: two hundred seventy faddāns of flax and a half and a quarter faddān (comes) four hundred and five dīnàrs. 
6 And from one faddān and a half and one half of an eighth of high quality flax (comes) one dinār and a half and one half of an eighth.

\section{Page 4}

1 Thereof: from one hundred and seventeen faddāns and a half and one eighth, one third of the faddān of flax (comes) three hundred and nine? ... and a half and one quarter and one sixth [faddāns].

2 And thereof: from twenty seven and [one eighth] and [one half of an eighth] faddāns is fifteen faddāns [ ] and one sixth.

3 The pulse, barley, trefolium and cartamus (safflower) from four hundred forty four and a half and a quarter (is) two hundred and nine and a half faddāns and one third and a quarter and one sixth.

Thereof: from three hundred and eighty nine faddāns and one eighth, flax: one faddān and half and one sixth? (is cultivated) two hundred and one faddāns.

\section{Page 5}

1 Folium, flax and calamus aromaticus (from) three faddāns (is) [ ] .. and one sixth and one half of an eighth.

2 Bakr, from two faddāns and one quarter and one sixth and one sixth of one eighth, flax: a half of a faddān (is) nine dīnārs and one sixth and one half of one fifth.

3 The pure income of the faddān: A half and one half of an eighth (is) one dinār and one fifth.

4 Thereof is now one thousand and three hundred and nine faddāns and a half and one fifth.

\section{Page 6}

1 The domains (are) one hundred eighty nine faddāns and a third and a fifth.

2 The [ ] forty? faddāns, the coast (is) forty faddāns

3 The conversion charge: from one thousand and five hundred and thirty three faddāns and a quarter and one sixth (is) one hundred and two dinārs and one third and one half of one sixth. The leguminous plants (are) one hundred and ten faddāns.

4 The rents (are) one dinār and a half and a quarter. Of what were arrears from one year and a half, thereof (is) one dīnār. 


\section{Page 7}

$1 \quad$ It has been approved thereof

2 Thereof: what has been carried to the town in various payments, and what has been carried to Thaqif ...... and what has been deposited at 'Alī. Now, he has acknowledged its price. All Praise belongs to God [

Thereof: what is guaranteed by Humayd Madhkūr ibn Salmī towards Salkh? ...

4 Bäbah and Amshìr: nine and a half faddān .. and a half and one third. Baramhāt one hundred fifty six faddāns and one sixth.

5 Baramūdah: two hundred forty one faddāns and a half. For grapes and $n a b q$ (fruit of the lotus): three hundred and nineteen faddāns and a half and one third and a quarter.

6 And thereof what I have collected and dispatched, and I wrote for a period of sufferance one and .... [ ] one hundred and seventy seven faddāns and one third and a quarter and one sixth of one eighth.

7 Two thousand and one hundred and thirty one faddāns [ ] and a half and a quarter. The good (lands) six hundred and ....

8 Thereof []$\ldots$.

\section{Page 8}

$1 \quad]$.

$2 \quad$ ]. Cash for Nāṣr? one hundred dīnārs

3 ] Vac.

4 And thereof what has been approved for the judge Asad al-Allāh ibn Zayd and it has been recorded: ninety nine faddāns and two thirds.

5 Thereof what has been carried in kind: seventy faddāns and one quarter and one sixth.

6 A payment concerning twenty faddāns. Nineteen faddāns and one third and a quarter. A payment is paid on the account of the agent concerning thirty five [faddāns] (the payment is for) thirty four faddāns and a half and one third.

7 A payment concerning twelve 〈faddāns〉 (the payment is for) eleven faddāns. A payment concerning .... [(the payment is for) twenty? dīnārs.

8 Thereof what has been spent in (some) directions [ ] twenty one faddāns [ ] and a quarter? [

9 The rest is twenty [ faddāns? ] and one quarter [ 


\section{Commentary}

Page 1

1. The term ارتفاع relates to the result of the survey usually referring to gross receipts (Frantz-Murphy, The agrarian 34 n. 4, 101, P.Khalili I, pp. $63 \mathrm{ff}$. and cf. P.Cair.Arab. IV 265 and 266). A day'a is a rural property rarely extending beyond the area of a village, usually owned by a civilian and managed by a bailiff (wakil). If the holder of the day'a is a Muslim, he has to pay two kinds of taxes: first, the zakāt that should be paid by all Muslims, taking the form of a tithe ('ushr) (usually a fifth of the kharāj) (Lambton, State 215); secondly, the kharāj, which is a tax levied on agricultural lands and should be paid by Muslims and non-Muslims (Abū Yūsuf, Kharāj, 41). In the Abbasid East, the day' $a$ was administered by a different government office than that pertaining to kharāj lands (CPR XXI, p. 186 n. 3). درنجه can be read as Drinja, Dranja or Drunja. This town, in the kūra of Ihnās, could not be identified.

2. Medial long alif is written with scriptio defectiva in the date (Hopkins, Studies§10, a).

3. لله الحمد والمنة: The addition of a religious formula between the basmala and the main text is often found in literary and documentary texts (see Ibn Khaldūn, Muqaddima, 1: xxxi. Cf. المحد لله والشكر الله , P.Cair.Arab. I 54.2; والمحد الله كالمستحق).

\section{Page 2}

3. Seems to be corrected from ف which makes better sense grammatically. Min refers to the distance from a place (Wright, A grammar III: 132d), while the preposition $f \imath$ is used to refer to the place itself. So, one may consider that Ihnās itself was at some distance to the day'a. In Egypt, the term küra was used in the early Arab period to refer to an administrative district that had a town وكور مصر منسوبة إلى مدنها لأن بكل كورة مدينة :cf. al-Ya'qūbī, Buldān 331 (خصوصة بأمر من الأمور (Che administrative district of kūrat Ihnās is not mentioned in lists other than the one cited by al-Maqrīzī (Khițat 1: 72), where the kūra of the town of Ihnās is said to have consisted of ninety-five villages plus some kufür. Ibn Khurradādhbih also mentioned the kūra of Ihnās as one of the kuwar Miṣr (Masālik 81). For the frequent changes in the geographical extent of this administrative district which was combined with the administrative district of the kürat al-Bahnasā at certain periods, see Grohmann, Probleme 381-394 and P.Khalili I 66. Two towns are known by the name Ihnās (Yāqūt, Buldān 1:409-410), the first is located in Middle Egypt on the westbank of the Nile (now called Ahnās al-madīna), the second was called Ihnās al-ṣughrā (small Ihnās), and it was a large village in the kūra of al-Bahnasā. The town of Ihnās has been 
known by many names. Today it is sometimes called Ihnasiyya Umm al-Kimām, meaning "Ihnās, mother of the sherds." In Coptic it was called Hnēs/Ehnēs. Important since the early dynasties, its main god was Hershef assimilated by the Greeks to Heracles after which they called the city Heracleopolis Magna (see Maspéro et Wiet 1919, 28). The Arabic papyrus PERF 612 (dated 102/720) actually refers to it as هرقلوس, Haraqlūs (Maspéro et Wiet, Matériaux 28).

3. Ishāq is written with scriptio defectiva of the medial long a (Hopkins, Studies §10, a). The nisba can be restored as الف]ار] سى or البـاد[بى . In P.Cair.Arab. III 270, 4 (3rd/9th century) we encounter also an Isḥāq from Bādis. There are traces of the bottom of about 5 letters at the end of the line. One may read وزادت which agrees with the rest of the sentence written on the following line.

4. وأن [يت]حمل فى ذلك أبو رإضى]: The reading is uncertain.

الاستدوال: There is a half curve visible above the letter lām.

5. الصرف, the expenses, refers to a sum to be expended for the land. Grohmann translated this word as "conversion charge" (P.Cair.Arab. III 239.2) and "allowance for security" (P.Cair.Arab. III 283.3, 7) without explaining how he came to this meaning. The term فضل appears in P. Khalili I 2.14. Khan (P.Khalili I, p. 64) has noted that some other terms are used to express the survey increase such as زائد (al-Makhzumī, Minhāj 6o, 61, and al-Nuwayrī, Nihāyat 8:251), إفافة (alNābulusī cited in Cahen, Le régime 16-17), and تأريخ (al-Makhzumī, Minhāj 61; al-Nuwayrī, Nihāyat 8: $25^{\circ}$ and al-Qalqashandī, Șubh 3:458).

6. الأوسية is the Arabic rendering of the Greek ousia (Grohmann, Griechische $281 \mathrm{f}$.). Such estates had a special place in the social and economic life in Byzantine Egypt before the Arab conquest (Hardy, The large $113 \mathrm{ff}$ ).

7. المئة وستين دينا(ر) (المائة (et passim):There is an oblique slight ripple of a stroke written above the letter sin of the word wتينين which has no teeth, and the word (ر) is abbreviated.

\section{Page 3}

2. Around the end of the third/ninth century a legal discussion arose about the nature of kharāj. The final outcome of this discussion was that kharāj was considered as a rent on the land (Tabatabāì, Kharāj 201; Lambton, State 258) which had to be paid by whomever cultivated the land. After خراج أرض one should expect the kind of plant cultivated on the land, such as خراج القصب (see P.Cair.Arab. III 234.10). 
3. وثلثين وثمن the reading is uncertain.

4. Kharäj was assessed in cash from the end of the third/ninth century onwards, when an attempt was made to establish a unified system of accounting on the basis of the gold standard with a legal tariff for the exchange of the dirham. Hence the qualification din $\bar{a} r$ in this line and in other places in the text.

6. Kattān 'älā is fine flax (Latin Linum usitatissimum) contrasting the unqualified flax attested in other places in this text. The tax on flax in this text comes to one din̄ār per faddān. For flax, see further P.Cair.Arab. II, p. $46 \mathrm{f}$.

\section{Page 4}

1. The number may be 319 or 329 , or 339 , etc., because there is a letter $w \bar{a} w$ after the number nine, we expect a multiple of ten. In the lacuna a qualification such as faddāns may be restored (cf. p. 4, ll. 2, 3, 4). It is to be noted that the flax here as well as in line 4 is not a fine flax (see note to p. 3, l. 6).

2. عن سبعة وعشرين و [تمّ]ن و [نصفتم]ن الفدان may be read.

3. القطان (pulse) (s. qatniya). Pulse is the common name for members of the fabaceae (leguminosae), a large plant family, also called the pea, or legume. Legumes were equally important as fodder and forage plants. The pulse family also provides dyes, medicines and other commercial items such as flavorings, fibres, etc.

Sha'ir, barley (Latin hordeum vulgare, hordeum distichon and hordeum irregulare, see Hitchcock, Manual sv. "Barley"), is one of the most ancient of cultivated grains. Barley plants are annual grasses either harvested in winter or spring.

Qirț (Latin trefolium alexandrinum and trefolium resupinatum, see Schnebel, Die Landwirtschaft $213 \mathrm{ff}$ ), trefoil, was the most common fodder for animals in Egypt according to al-Suyūṭi (see al-muhāọdara 2: 231). Ibn 'Abd al-Ḥakam writes that trefoil was exempted from kharāj tax (Futūh 153), but in Arabic papyri we find assessments for this plant (P.Cair.Arab. III 231 n. 4). For kharāj on trefoil, see for example P.Ryl.Arab. VII 19.4, and P.Cair.Arab. IV 231.4 and commentary.

Qurțum, safflower (Latin Carthamus tinctorius), is identified by Ibn Manzūur qurtum as saffron (Lisān sv. قرطم). Safflower is one of humanity's oldest crops. The Arabic name lays at the origins of the general pharmaceutical name flores carthami. The Arabic name is derived from the verb qartama (to dye) in reference to the use of safflower flowers for textile dyeing. Its modern Arabic 
name usfur (saffron), from asfar, yellow, has entered many languages through the mediaeval Andalusian pronunciation.

5. (وا |حد فدا (ن) ونصف وربع وسد): The reading of this line is uncertain.

(ن) (ن اوند (ن) : the Küfan grammarians allow the placement of the adjective of the cardinal number if the genitive is an object (see Ibn Hishām, Shudhūr 1: 216

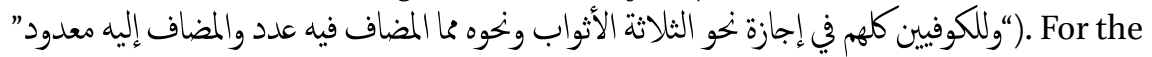

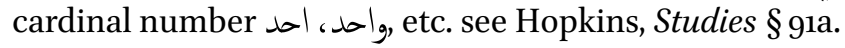

\section{Page 5}

1. ساذج . سذاج (Latin folium). This word is known to have been written with the alif as third or second letter. Ibn Sinā (d. 1037) describes the plant and its medicinal use (Ibn Sīnā, al-Qānūn fì al-țīb s.v. ساذج).

Al-qașab al-färisī (Latin calamus aromaticus) is a sort of reed, or sweetscented cane, without branches, with a crown at the top, and beset with spines, about two feet in height, bearing from the root a knotted reddish stalk, quite round, containing in its cavity a soft white pith. It grows in Egypt, Syria, and India and is said to make the air scent while growing. When cut down, dried and powdered, it forms an ingredient in the richest perfumes and is used in medicine (see Webster's New International Dictionary of the English Language sv. "Calamus"). Frantz-Murphy translates the name of the plant literarily as "Persian reeds" (The agrarian 34, 18).

\section{Page 6}

1. A careless curved joint line links the alif and lām so one can read the word as الأضياع.

3. The reading of الخـــ, vegetables, is uncertain. After the article the letter may be jim or $k h \bar{a}$. Vegetables are frequently mentioned in Arabic papyri (see for example P.Cair.Arab. III 266.7; 268.14). For kharāj on leguminous plants, see PER. Inv. Ar. Pap. 10151, 13.

\section{Page 7}

2. الحضرة: means the "town." See Ibn Manzūur, Lisān, sv. "حضر."

ثقيف: the reading is uncertain. Thaqif is an Arab tribe living to the south-east of Mecca (Kister, Mecca 134).

قَّبل [ع] للى الان فقر بتمنيه the tribe of Thaqif. He acknowledges that he has received some of what has been collected from the kharāj. 
3. سلح: its diminutive name is سلخغ, as recorded in al-Dhahabī, Mushtabah 271.

5. Inab are more frequently attested in the papyri as kurüm, vineyards. For viticulture, see P.Cair.Arab. I, p. 10. Here there is clearly mention of the production of the vineyards as well as the lotus tree (i.e. Nabq).

Nabaq are the fruits (cones) of the lotus, sidr or cedar tree. The lotus is a large hardwood tree, which can grow more than 5 meters high (Nour and Ahmed, A chemical 271-273) and bears a round and yellowish cherry-like fruit (al-Anțākī, Tadhkirat 186 f.; Ibn al-Bayțār, Jāmic $3: 4,32$ ). The fruit is used for food and as a medicine (Kamal, The ancient $305 \mathrm{ff}$.). The tree is mentioned in the Quran as a tree in the afterlife in whose shade the righteous will recline (Q 56:28).

6. For batha in the sense of 'dispatch,' see P.Cair.Arab. IV 401.1-12.

\section{Page 8}

6. The payment should be for 20 faddāns but what has been paid was for only 19 faddāns and one third and one quarter, which means that $5 / 12$ faddān has not been farmed.

7. اثنى عشر: the reading is uncertain. (ف)|(ن) should be added (cf. l. 6 on the same page).

9. البواقى عشرون: may be read.

2

Instructions Concerning Funerals

P. ACPSI 126 (P. Rag.) Provenance unknown (outlined left) figs. 14.5-14.6 $15 \times 8.5 \mathrm{~cm}$. ca. 2 nd /8th century

The papyrus is broken off at the bottom, the left and right sides. It is damaged at the right and bottom sides, though the original margin has remained at the top. The papyrus, which was folded four times from left to right, is of light brown colour, fairly fine. A small piece measuring $5 \times 0.8 \mathrm{~cm}$ and bearing about six upper halves of letters is torn off on side A.

The text was written on both sides of the papyrus, in black ink, in a neat, elegant hand pointing to the beginning of the second/eighth century. Diacritical points are rarely used. The side where the writing goes perpendicular to the fibres was written first, after which the scribe continued on the other side. There is a correction above line one which can be read while the superscript 
of line three can only be partly read. The end of each hadith is indicated with a circular sign.

The text was probably longer than the thirteen lines written on both sides of the papyrus. The writer presents the ahädith sometimes in his own words (A1), other times by citing them literally (B4). The text contains both prophetic and companions' ahàdīth, and all the transmitters are known in these traditions.

The place of discovery is unknown.

\section{Side A (Fig. 14.6)}

$$
1
$$

2

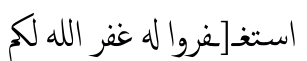

[واخبرنى عن 'يميى بن زيد ----- عن أبى سعيد حفص بن ميسرة عن أبى لاعمر الصحابى]

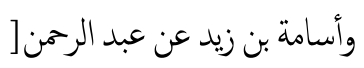

4

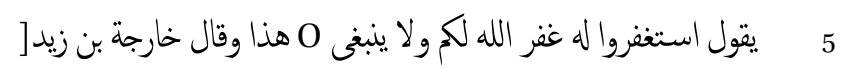

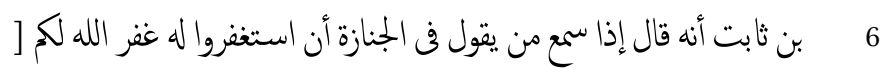
7 ]

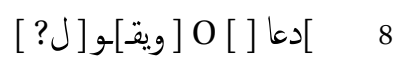

Side B (Fig. 14.5)

$$
\begin{aligned}
& 1 \\
& 2 \\
& 3 \\
& 4 \\
& 5
\end{aligned}
$$




\section{Translation}

Side A

1 ] Rāfic [has reported that] Abū Hurayra commanded his family to be careful not to apply any perfume on him and not to shroud him in red velvet (after death) [

2 ] He said, and it has been reported to me, about Abū Sa'īd al-Khudrī that he inclined towards the red velvet. The one who was behind the funeral harms them (the death) by saying: "Ask forgiveness [for him. May God forgive you."

3 ] And he reported to me on the authority of Hafs ibn Maysara on the authority of Yahyā ibn Zayd — on the authority of Abū Sa'īd 【'Umar alȘahābī $\rrbracket$ and Usāma ibn Zayd on the authority of 'Abd al-Raḥmān [

4 ibn Harmala al-Aslamī on the authority of Sa'ìd ibn al-Musayyab that he said: "Look at your poet who [

5 says: "Ask forgiveness for him, God forgives you." This is not allowed." In addition to this, Khārija ibn Zayd [

6 ibn Thābit said that he said: "If it is heard that the man behind the funeral says: "Ask forgiveness for him, God forgives you [

7 ] being said [ ] he says [ ] and that is with God alone [ ] .... [ ] O. He said: "The one who [ ] said [

$8 \quad$ ] pray [ ] $\mathbf{O}$. And [he] says [

\section{Side B}

1 And 'Amr ibn al-Hārith on the authority of Bukayr ibn al-Ashajj on the authority of Bisr ibn Sa'īd, that the Prophet said: "The eyes are shedding tears

$2 \quad$ and the heart is grieved. Do not scream." He (also) said I wept and the Prophet wept for his sons, and he (the Prophet) said: "Weeping is

3 from mercy and screaming is from the devil." $\mathbf{O}$ And he reported to me on the authority of Ibn Jurayj that the messenger

4 of God said: "The eyes are shedding tears and the heart is grieved and we will not say what enraged God."

5 (vac.) And Peace is upon those who are in the graves.

\section{Commentary}

Side A

1. Rāfi ibn Khadīj (al-Dhahabī, Muqtanā 1:214 no. 1944) died when he was 86 years old in 73/692 or 74/693 (al-Bustī, Thiqāt 3:121 no. 407). He lived and 
died in Madīna (al-Dhahabī, Muqtanā 1:467 no. 1778). At the battle of Badr this companion from the Khazraj was deemed too young to fight (Juynboll, Encyclopedia 10). Abu Hurayra (d. 59/687) is the well-known companion and hadīth transmitter (Ibn Sa'd, Tabaqāt 4:325; Ibn 'Abd al-Barr, Istī āb 4:202; Juynboll, Encyclopedia 45-47). He appears very frequently in isnāds of hadīths. This hadith is not known to have been transmitted on the authority of Abū Hurayra nor on that of Rāfi', although both stipulated conditions in their will about how their body should be dealt with after their death. Abū Hurayra forbade the use of a majmara (censer) (Ibn Abī Shayba, Muṣannaf 2:472 no. 11170).

Awșa (أوصى . أوصا) is written with alif mamdūda (Hopkins, Studies §12c). The verb awșā was used in some ahādìth in relation to red velvet and rajaz (see commentary to B4) (Ibn Sa'd, Țabaqāt 5:142; 8:74).

Hadhirū fì allā yuzhirū 'alayhi al-țīb. Verbs signifying 'to forbid,' 'fear,' and the like, are followed by an with the subjunctive. The negative $l \bar{a}$ is sometimes inserted after an without affecting the meaning. Cf. annī akhäfu allä yatrakanī, "I am afraid he will not leave me," or "I am afraid he will leave me" (Wright, $A$ grammar $2 \S 15$ a). Al-tīb refers to well-scenting fragrances. The use of essences in the treatment of the deceased body is described in several hadiths. In a hadith narrated by Umm 'Ațiyya, one of the anșār, she said that Muhammad instructed her when she was giving a bath to his deceased daughter saying: "Wash her three, five or more times with water and $s i d r$, lotus, and sprinkle camphor on her at the end. When you finish, notify me." (al-Bukhārī, Șaḥịh no. 1183). Ibn Mas' ūd in another hadith reported that the body of the deceased should be dried after washing with a clean cloth and some camphor should be applied to the sujüd parts (those parts of the body that touch the ground during prayer) (al-Bukhārī, Șahịh no. 6495).

Wa-lā yaj'alūhu fi qațīfa ḥamrā. When Rāfic ibn Khadīj died, his bed was covered in red velvet to the astonishment of the people (Ibn Hanbal, Musnad no. 16637). See also the commentary to line 2. After the Prophet's death, his mawla $\bar{a}^{6}$ Shuqrān threw a red velvet burda (cloak) on the dead body because Muhammad had disliked wearing another one (Muslim, Șahịh no. 967, and alRāzī, Jarh 6:164). It is also said that Shuqrān placed the red villous cloth (qațīfa) in the Prophet's grave to prevent others from using it (Juynboll, Encyclopedia 523).

Based on the prophet's burial and expressed preferences, the shroud normally used by Muslims consists of white cloths. Samura ibn Jundab (d. ca. $5^{2-}$

6 It is said that 'Abd al-Raḥmān ibn 'Awf (d. 32/652) either donated or sold Shuqrān, the Ethiopian, to the Prophet who set him free after the battle of Badr (al-'Asqalānī, Qawl 5:80). 
53/672-673) reported that Muhammad said: "Wear white. It is purer and more wholesome, and shroud your dead in it" (al-Bayhaqī, Madkha, 3:402). 'Ā'isha (d. 58/678) reportedly said: "God's messenger was shrouded in three garments of white Yemeni fabric, amongst which was neither a shirt nor a turban" (Abū Dāwūd, Sunan, Kitāb al-Janā'iz 20:3145). Children are shrouded in one to three pieces of cloth. Young females are shrouded in a shirt and two wraps. Males are covered by three pieces of cloth, and adult females in five.

2. Abū Sa'ìd al-Khudrī (d. 74/693) held the full name, Sa'd ibn Mālik ibn Sinān. He was one of the prophet's companions and transmitted many prophetic hadīths. (Ibn Sa'd, Tabaqāt 5:142). In spite of the statement in this text, it is said that Abū Sa'īd al-Khudrī demanded that at his funeral no rājaz (see commentary on B4), or censer should be present, and that his body should not be carried on red velvet (Ibn Sa'd, Tabaqāt 5:142).

A] d̦arra bihim alladhī yaqūlu khalfa al-janāza 'istaghfarū lahu ghafara allāh lakum. For the restoration of this sentence, see the commentary to lines B4-5.

The negative sense of أضرى is contradicted by hadiths showing that the Prophet approved of the custom to ask for forgiveness of the deceased while following his funeral procession ( janāza) (Muslim, Șaḥ̆ḥ no. 2094).

3. The scribe began to write Abī as part of the name of Abū Sa'ìd but then continued to write the name 'Umar al-Ṣahāaì. He then crossed out the name 'Umar al-Ṣahābī and returned to write the full name of Abū Sa'ìd without deleting Abì that he had already written and adding Sa'îd above the line. Between the name of Yahyā ibn Zayd and Abū Saīd there are traces of some illegible letters.

'Abd Allāh ibn 'Umar al-Ṣahạābī is 'Abd Allāh ibn 'Umar ibn al-Khaț̣āb ibn Nufal, also known as Abū 'Abd al-Rahmān (d. 73/692), belonging to the tribe of al-'Adawī al-Qurayshī (cf. Juynboll, Encyclopedia 10-11). He lived in Madīna and died in Marw. 'Abd Allāh was renowned for his close observation of the Prophet's actions as observed by 'Ā'isha: "There was no one who followed the prophet's footsteps as did Ibn 'Umar." He would only relate a hadith if he was completely sure that he remembered every word of it. One of his contemporaries said: "Among the companions of the Prophet, no one was more cautious about adding to or subtracting from the hadith of the prophet than 'Abd Allāh ibn 'Umar (see Ibn Ḥajar, Iṣāba no. 4825)." Yahyāa ibn Zayd (d.63/682) is Yahyā ibn Zayd ibn Thābit ibn al-Ḍahāk (Ibn Sacd, Ṭabaqāt 5:264). He was killed at the battle of Harra in 63/683 (Ibn Sa'd, Tabaqāt 5:236). His brother is Khārija ibn Zayd ibn Thābit, for whom see the commentary to B5. Abū Sa'ìd is Abū Sa'īd al-Khudrī for whom see above in the commentary to A2. Hafș 
ibn Maysara al-Kan`anī al-'Asqalānī (d. 181/797) (al-Dhahabī, Muqtanā 1:422, no 4522; Juynboll, Encyclopedia 403). According to some scholars he came from the town of San 'â' in Syria while others identified it with the town with the same name located in Yemen (al-Bukhārī, Tārīkh al-Ṣaghīr 2:369; al-Mizzī, Tahdhīb al-kamāl 7:73, no. 1417). He was considered a reliable source for hadìths. Usāma ibn Zayd (d. ca. 54/674) was the son of Zayd ibn Hārith, a manumitted slave and the Prophet's adopted son who became one of his companions (Ibn 'Abd al-Barr, Istī' $\bar{a} b$ 1:77; 3:1137-1140, and Fu'ad 2003, 8, 161). Some weeks before his death, Muhammad appointed Usāma, still quite young and unexperienced at the time, at the head of a large expedition against Syria, which caused some of the leading muslims to complain. Usāma died in al-Jurf and was buried in Madīna (Vacca, EI s.v.).

4. 'Abd al-Raḥmān ibn Ḥarmala (d. 145/762) was a well-educated member of the Banū Mālik ibn 'Aqșa, belonging to Madīna's élite (al-Bustī, Mashahīr 1:137 no. 1081). He reported on the authority of Sa'ìd ibn al-Musayyab (d. 94/712) as we have here and others (al-Maqdisī, Ahādīth 4:233; al-Khurāsānī, Sunan 1:309 no. 1107). Sa'īd ibn al-Musayyab is Sa'ìd ibn al-Musayyab ibn Ḥazan ibn Abī Wahhāb ibn 'Amr also known as Abū Muhammad, belonging to the tribe of al-Quraysh. He lived and died in Madīna (Ibn Abī Shayba, Mușannaf 7:19, 24; al-Qurțubī, Jāmic 8:239; Ibn 'Abd al-Barr, Istī'āb 1:77; 3:1137-1140; al-Ṭabarī, Bayān 10:68).

The rājiz recites poems in the rajaz meter. According to different authorities, performing rajaz at funerals is forbidden in Islam. Abū Muțī' narrated that 'Abd al-Raḥmān ibn Ḥarmala was at a funeral when he heard a man saying: "Ask God's forgiveness for her, and Saīd ibn al-Musayyib said: What is their poet saying? I commanded my wife not to call their poet (at my funeral)" (Ibn Abī Shayba, Muṣannaf 11:198; Ibn Sa'd, Ṭabaqāt 5:141).

5. Istaghfarū lahu ghafara allāh lakum wa-lāyanbaghī. Correct would have been istaghfarū lahu ghafara allāh lahu as is mentioned in certain ahädìth, such as: The Prophet came to them (his companions) and said: "Ask forgiveness for Māciz ibn Mālik." They said: "May God forgive Māiciz ibn Mālik” (al-Nasā̄ì, Sunan 4:276). Cf. Ibn Abī Shayba, Muṣannaf 2:474 nos. 11193; 11194 and 11199; al-Bustī, Thiqāt 1:405 no. 6975. In general the șaḩäba are said to have disliked the raising of loud voices at funerals (al-Bayḥaqī, Madkhal 4:74 nos. 6974-6975).

Although the word is dotted the reading is doubtful.

5-6. Khārija ibn Zayd ibn Thābit (d. 99/717 or 100/718) was a great traditionist who transmitted few aḥādìth (Ibn al-Qayșarānī, Tadhkirat 1:91 no. 82; al-Ijlī, 
Ma'rifat 1:330 no. 385). He was also a great faqīh who was being consulted on matters of Islamic law (al-Dhahabī, Siyar 4:439-440). Khārija claimed that at the order of the Prophet he learned Hebrew so that he could "write and read the letters of the Jews," in half a month (al-Dhahabī, Siyar 17:467). He was one of the anșār.

6. Idhā sumi'a man yaqūlu fí al-janāza istaghfarū lahu ghafara allāh lakum. We expect a sentence to follow such as فانهوه, then prevent him, or then stop him.

\section{Side B}

1. 'Amr ibn al-Hārith, written with defective long a (see Hopkins, Studies §10 a), (d. 148/765 or 149/766) belonged to the tribe of al-Anșarī (al-Bustī, Mashāhìr 1:187 no. 1498; al-Ișfahānī, Hilyat 2:540 no. 846). He lived in Egypt and he was known as faqīh al-dayār al-Mișriyya. The well-known Egyptian scholar 'Abd Allāh ibn Wahb (d. 197/812) was his most famous transmitter (Juynboll, Encyclopedia $11 \mathrm{n}$. 3). He was considered to be a reliable muhaddith, famous for his knowledge of religious philology, as an eloquent narrator of poems and an orator (al-Ḥākim al-Nīsābūrī, Mustadrak 1:2093). Bukayr ibn al-Ashajj (d. 115/733?) was also known as Abū 'Abd Allāh, as well as Abū Yūsuf al-Qurayshī al-Madanī al-Mișrī, because he spent some time in Egypt. He lived in Madīna. Bisr ibn Saīd (d. 100/718) was born in Madīna. He was considered a reliable hadīth transmitter and was also considered to be a șūfì (al-Iṣfahānī, Rijāl 1:96; al-Dhahabī, Siyar 5:113).

2-3. Wa bakāal-nabì alä banīhi wa-qāla al-bukā'min al-raḥma wa-l-ṣurākh min al-shayțān. Bakā is written with an alif mamdüda instead of an alif maqsūra. It seems that the writer began to write الأبناء (the sons) but he changed his mind and wrote بن (his sons) without effacing the article. The Prophet begot four daughters and three sons, the latter of whom all died as young children. Muhammad is said to have cried at the death of his children and grandchildren allowing tears and sadness to show but forbidding such pre-Islamic customs as tearing ones' clothes, slapping face and wailing loudly at someone's death. ${ }^{7}$ (al-Bayhaqī, Madkhal 4:6941, 6943; Ibn Ḥanbal, Musnad no. 25267; al-Nawawī, Sahịh Muslim 2:110, and 6:224-225). This hadïth is not known to have been

7 For an example of pre-Islamic funerary customs, note the lines of the poet Tarafa ibn al-'Abd (d. c.E. 569): "When I die, mention my qualities as befits me, and rend your garments for me, o daughter of Macbad. Do not make me like a man whose aspirations are not my aspirations, who could not do what I could do, or play the role I play (al-Nawawī, Riyād 86). 
transmitted on the authority of Bisr ibn Sa ${ }^{c} 1 \bar{l}$ but on that of Anas ibn Mālik (d. 93/712) (al-Bukhārī, Șaḥị̣ no. 1220).

3. Ibn Jurayj (d. 150/767), in full, 'Abd al-Malik ibn 'Abd al-'Azīz ibn Jurayj (al-Dhahabī, Siyar 6:325, no. 138; Juynboll, Encyclopedia 212-225) is said to have been a mawlā of Umayya ibn Khālid and to have been of Byzantine descent (al-Dhahabī, Siyar 6:325-336).

4. Tadma'u al-'ayn wa yahzanu al-qalb wa-lā naqūlu māyaskhitu al-rabb. This is a part of the same hadith discussed above (see note B2-3). It is set at the dying of Ibrāhīm, the Prophet's son. Muhammad entered upon his son Ibrāhīm as he was surrendering his soul (i.e., dying). Tears began to well up in the Prophet's eyes. 'Abd al-Raḥmān ibn 'Awf said to him: "Even you, o messenger of God?" He said: "O, Ibn 'Awf, this is compassion." Then he wept some more and said: "The eyes shed tears, and the heart feels grief, but we will not say what enraged the Lord. And truly we are deeply grieved by your departure, o Ibrāhīm" (Muslim, Sahịh no. 1578).

5. Salām is written with defective long a (see Hopkins, Studies §9 c). When visiting the tombs Muslims should say "peace be upon you, o people who inhabit the graves (three times), you are the predecessors and we are the successors" (al-Ṭabatānī, Mujam 8:129 no. 8178).

\section{Bibliography}

\section{Primary Sources}

Abū Dāwūd (d. 275/889), Sunan Abì Dāwūd. Cairo 1987.

Abū Yūsuf (d. 182/798), Kitāb al-Kharāj, Cairo 1382/1962.

al-'Asqalānī (d. 852/1448), Fath al-bārī bi-sharh Ṣaḥị̣ al-Bukhārī, ed. M.F. 'Abd al-Bāqī et al., Beirut 1379/1959.

_. al-Qawl al-musaddad fíal-dhabbian al-musnad li-al-Imām Aḥmad, Cairo 1401/ 1980.

al-Bayhaqī (d. 458/1065), al-Madkhal ilā al-sunan al-kubrā, ed. M. 'A.R. al-A`ẓamī, Kuwait 1404/1983.

al-Bukhārī (d. 256/870), Șaḥịh, ed. A.M. Kalābādhī and A.A. Laythī, Beirut 1987 .

_. al-Tärīkh al-kabīr, 8 vols., Cairo s.d.

- al-Tārīkh al-ṣaghīr, 2 vols., ed. M.I. Zāyid, Cairo 1397/1977.

al-Bustī (d. 354/865), Mashāhīr 'ulamā’ al-amșār, ed. M. Fleishhammer, Beirut 1959. . Kitāb al-Thiqāt, 9 vols, ed. Sharaf al-Dīn Aḥmad, Cairo 1395/1975. 
al-Dhahabī (d. 748/1347), al-Muqtanā fı̀ sard al-kunā, 2 vols., ed. M.Ṣ. 'Abd al-'Azīz, Madīna 1408/1987.

_. Siyar a lām al-nubalā', 23 vols., ed. Sh. al-Arna'ūṭ et al., Beirut 1413/1992. Kitāb al-Mushtabah fi asmā' al-rijāl, Cairo 1962.

al-Ḥākim al-Nīsābūrī (405/1014), al-Mustadrak 'alā al-ṣaḥịhayn, 4 vols., ed. M. 'Abd al-Qādir, Beirut 1411/1990.

Ibn 'Abd al-Barr (d. 463/1044), al-Istī 'āb fi ma' rifat al-aṣhāa b, 4 vols., ed. A.M. al-Bajāwī, Beirut 1412/1991.

Ibn 'Abd al-Hakam (d. 257/871), Futūḥ Miṣr, ed. Ch. Torrey, The history of the conquests of Egypt, North Africa and Spain, New Haven 1922.

Ibn Abī Shayba (d. 235/849), al-Kitāb al-Mușannaffì al-ahāäìth wa-l-athār, 7 vols., ed. K.Y. al-Hut, Riyadh 1409/1988.

Ibn al-Bayțār (d. 645/1248), Kitāb al-Jāmi li-mufradāt al-adwiya wa-l-aghdhiya, Cairo 1291/1874.

Ibn Ḥajar (d. 852/1449), al-Ișāba fi tamyīz al-ṣaḥāba, Cairo 1967.

Ibn Hanbal (d. 241/855), al-Musnad, ed. A. al-Banna, Cairo 1980.

Ibn Hishām (d. 671/136o), Sharh shudhūr al-dhahab fı ma'rifat kalām al-'arab, ed. 'Abd al-Ghanī al-Daqr, Damascus 1984.

Ibn Khurradādhbih (d. ca. 30o/912), al-Masālikwa-l-mamālik, ed. M.J. de Goeje, Leiden 1889.

Ibn Khaldūn (d. 808/1406), Les prolégomènes d'Ibn Khaldoun, ed. M.C. De Slane, Paris 1883.

Ibn Manzūur (d. 711/1311), Lisān al-'arab, 6 vols., ed. 'A.A. 'A. al-Kabīr et al., Cairo 1981.

Ibn al-Qayṣarānī (d. 507/1113), Tadhkirat al-huffāz, 4 vols., ed. Ḥamdī al-Salafì, Riyadh 1415/1994.

Ibn Sīnā (d. 1037), al-Qānūn fí al-țibb, Cairo 1877 .

al-Ijlī (d. 261/877), Ma'rifat al-thiqāt, 2 vols., ed. 'A. al-Bustawī, Madīna 1405/1985.

al-Ișfahānī (d. 430/1038), Hilyat al-awlīyā'wa țabaqāt al-asffyā', 10 vols., Beirut 1405/1984.

—. Rijāl Ṣahịh Muslim, 2 vols., ed. 'A.A. al-Laythī, Beirut 1407/1987.

al-Khurāsānī (d. 227/89o), Kitāb al-Sunan, ed. Ḥ. al-A‘ẓamī, Bombay 1982.

al-Makhzūmī (d. 585/1189), Kitāb al-Minhāj fi 'ilm kharāj Miṣr, eds. Cl. Cahen and Y. Rāgib, Cairo 1986.

al-Maqdisī (d. 643/1245), al-Ahāàìth al-mukhtāra, 10 vols., ed. 'A. Duhaysh, Mecca 1310/ 1893.

al-Maqrīzī (d. 845/1442), al-Mawāiz wa-l-i'tibār fì dhikr al-khițațwa-l-āthār, Cairo 1987. al-Mubārakfūrī (d. 1353/1934), Tuhfat al-aḥwadhī bi-sharh al-Tirmidhī, 10 vols., Beirut s.d.

al-Mundhirī (d. 656/1258), al-Targhīb wa-l-tarhīb min al-hadīth al-sharīf, ed. I. Shams al-Dīn, Beirut 1417/1996.

al-Mizzī (d. 742/1341), Tahdhīb al-kamāl, 35 vols., ed. B.'A. al-Ma'rūf, Beirut 1985-1992. 
al-Nawawī (d. 676/1277), Saḥị̣ Muslim bi-sharḥ al-Nawawī, 18 vols., Beirut 1392/1972. - Riyā ạl-ṣālihịn, ed. 'A.'A. Rabāḥ and A.Y. al-Daqqāq, Riyadh 1413/1993.

al-Nasā'̄i (d. 303/915), Kitāb al-Sunan al-kubrā, 6 vols., ed. 'A.Gh.S. al-Bundārī et al., Beirut 1411/1991.

al-Nuwayrī (d. 733/1333), Nihāyat al-'arab fífunūn al-adab, Cairo 1923. al-Qalqashandī (d. 821/1418), Șubh al-a shà fì șinā́at al-inshā, Cairo 1903. al-Qurțubī (d. 671/1273), al-Tafsīr, 20 vols., ed. A.'A. al-Bardunī, Cairo 1372/1952. —. al-Jāmi' li-aḥkām al-Qurāàn, 20 vols., Cairo 1372/1952.

al-Rāzī (d. 327/938), al-Jarh wa-l-tacdīl, 9 vols., Beirut 1271/1952.

al-Ruwayānī (d. 307/919), Musnad al-Ruwayānī, 2 vols., Cairo 1416/1995.

Ibn Sa'd (d. 230/844), al-Ṭabaqāt al-kubrā, 8 vols., Beirut s.d.

al-Suyūṭī (d. 911/1505), Husn al-muhạạara, Cairo 1968.

al-Ṭabarī (d. 310/922), Jāmi' al-bayān 'an ta'wül ayat al-Qur'ān, 30 vols., Beirut 1405/1984. al-Ṭabatānī (d. 36o/970), al-Mujam al-wasịt, Cairo 1415/1994.

al-Ya'qūbī, Kitāb al-Buldān. ed. M.J. De Goeje, Leiden 1892.

Yāqūt al-Ḥamawī (d. 626/1229), Kitāb Mujam al-buldān, Teheran 1965.

\section{Secondary Sources}

Abashin, S., The logic of Islamic practice: a religious conflict in Central Asia, in Central Asian Survey 25 (2006), 267-286.

al-Anțākī, D., Țadhkirat ūlì al-albāb wa-l-jāmi 'li-l-'ajab al-'ujāb, Cairo 1952.

Becker, F., Islamic reform and historical change in the care for the dead: Conflicts over funerary practice among Tanzanian Muslims, in Africa 79 (2009), 416-434.

Cahen, C., Le régime des impôts dans le Fayyūm Ayyūbide, in Arabica 3 (1956), 8-30.

Casson, L. and E.L. Hettich, Excavation at Nessana, vol. II, literary papyri, Princeton 1959.

Diem, W., Einige frühe amtliche Urkunden aus der Sammlung Papyrus Erzherzog Rainer (Wien), in Le Muséon 97 (1984), 109-158.

Federspiel, H., Persatuan Islam: Islamic reform in twentieth-century Indonesia, Ithaca NY 1970, repr. 2009.

Frantz-Murphy, G., The agrarian administration of Egypt from the Arabs to the Ottomans, Cairo 1986.

Grohmann, A., Griechische und lateinische Verwaltungstermini im arabischen Ägypten, in Chronique d'Égypte 13/14 (1932), 275-284.

. Probleme der arabischen Papyrusforschung, in Archiv Orientální 3 (1931), 381-394.

—. Probleme der arabischen Papyrusforschung II, in Archiv Orientální 6 (1934), 377-398.

Halevi, L., Muhammad's grave: Death rites and the making of Islamic society, New York 2007 . 
Hardy E.R., The large estates of Byzantine Egypt, New York 1931.

Hitchcock, A.S., Manual of the grasses of the United States, Washington 1951.

Hopkins, S., Studies in the grammar of early Arabic, Oxford 1984.

Juynboll, G.H.A., Encyclopedia of canonical hadith, Leiden 2007.

Kamal, H., The ancient Egyptian medicine, Cairo 1964.

von Karabacek, J., Der Papyrusfund von El-Faijūm, in Denkschrift der Philosophischhistorischen Classe der Kaiserlichen Akademie der Wissenschaften 33 (1882), 215-230.

Kister, M.J., Mecca and Tamīm (aspects of their relations), in Journal of the Economic and Social History of the Orient 8 (1965), 113-163.

Lambton, A.K., State and government in medieval Islam, Oxford 1981.

Maspéro, J. and G. Wiet, Matériaux pour servir à la géographie de l'Égypte, in Mémoires publiés par les membres de l'Institut Français d'Archéologie Orientale du Caire 36 (1919), 1-282.

Nour, A.A. and A.R. Ahmed, A chemical study of Zizphus Spina-Christi (Nabag) fruits grown in Sudan, in Tropical science 27 (1987), 271-273.

Pellat, Ch., Fuḳahā' al-madīna al-saba', in Encyclopaedia of Islam. New edition. s.v.

Schnebel, M., Die Landwirtschaft im hellenistischen Ägypten, Munich 1925.

Smith, J.I. and Y.Y. Haddad, The Islamic understanding of death and resurrection, Albany NY 1981.

Tabatabāî̀, H.M., Kharāj in Islamic law, London 1983.

Vacca, V., Usāma b. Zayd, Encyclopaedia of Islam. New edition. s.v.

Webster's Collegiate Dictionary (http://www.merriam-webster.com/).

Wright, W., A grammar of the Arabic language, Cambridge 1967. 


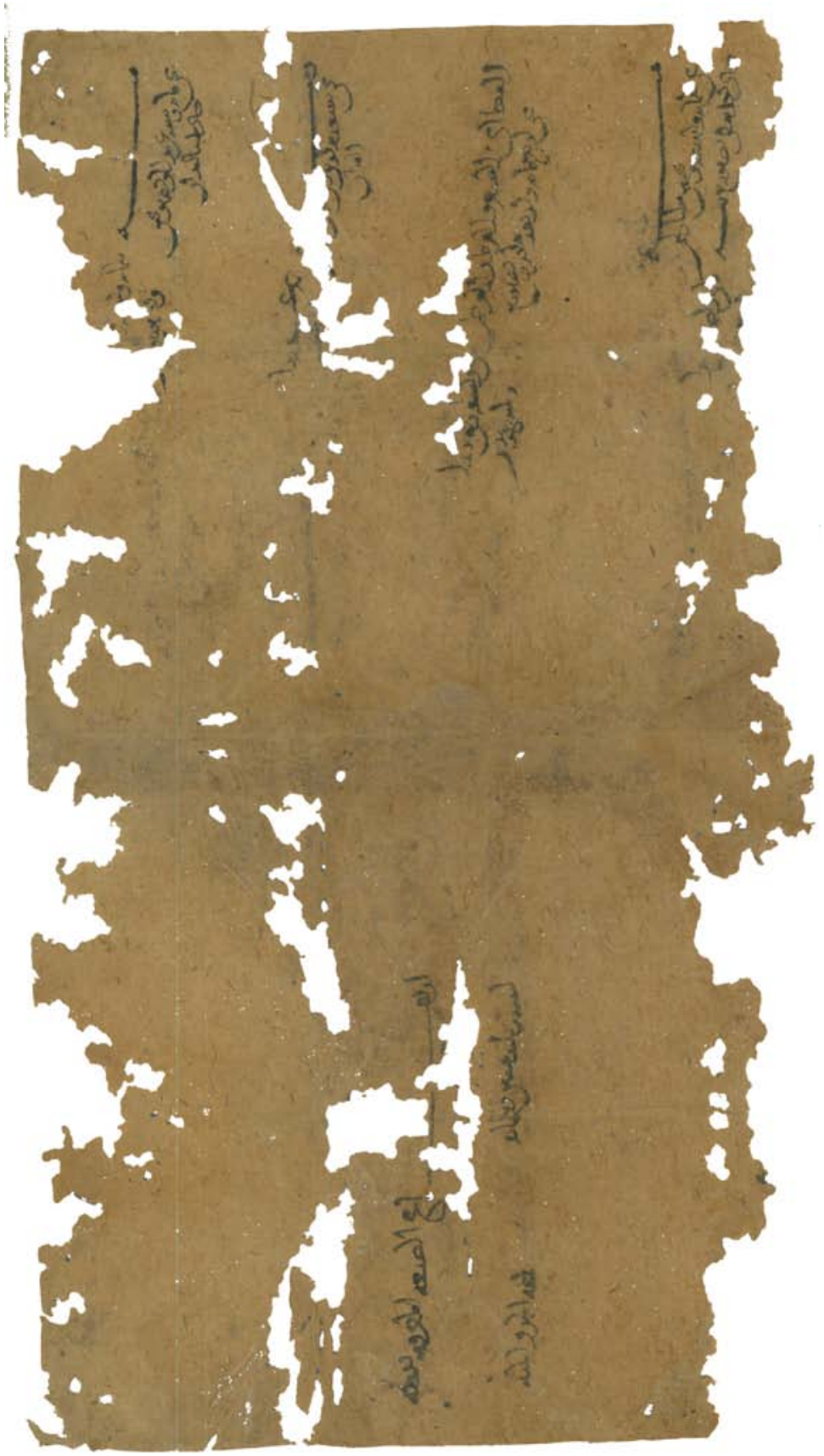

FI G. 14.1 P. Haun. Inv. Arab. 21 recto. Courtesy of the Papyrus Carlsberg Collection. The P.Haun. collection is now housed together with the P. Carlsberg collection in Copenhagen, but the manuscripts retain their original inventory numbers. 


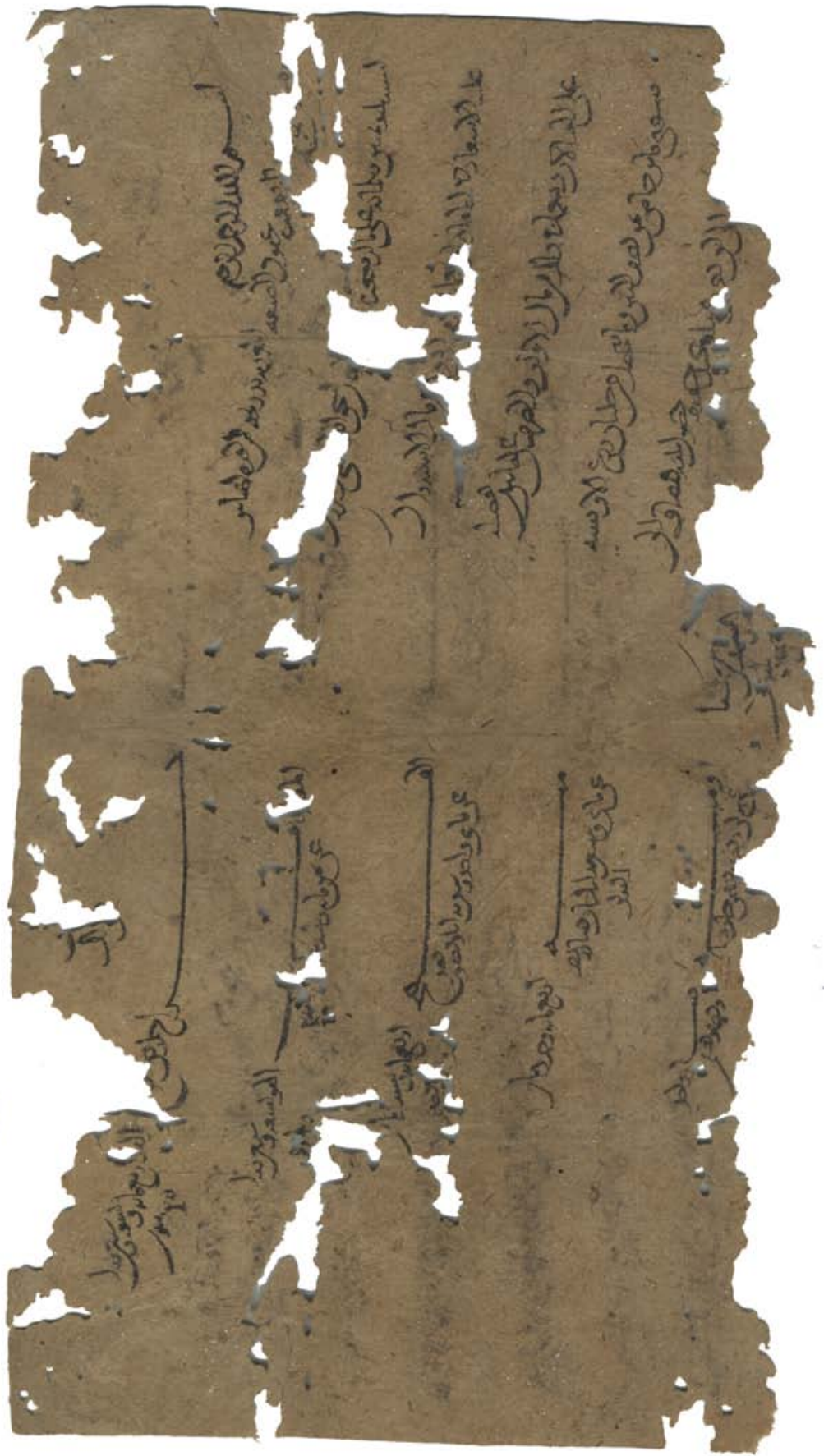

FIG. 14.2

P. Haun. Inv. Arab. 21 verso. Courtesy of the Papyrus Carlsberg Collection. 


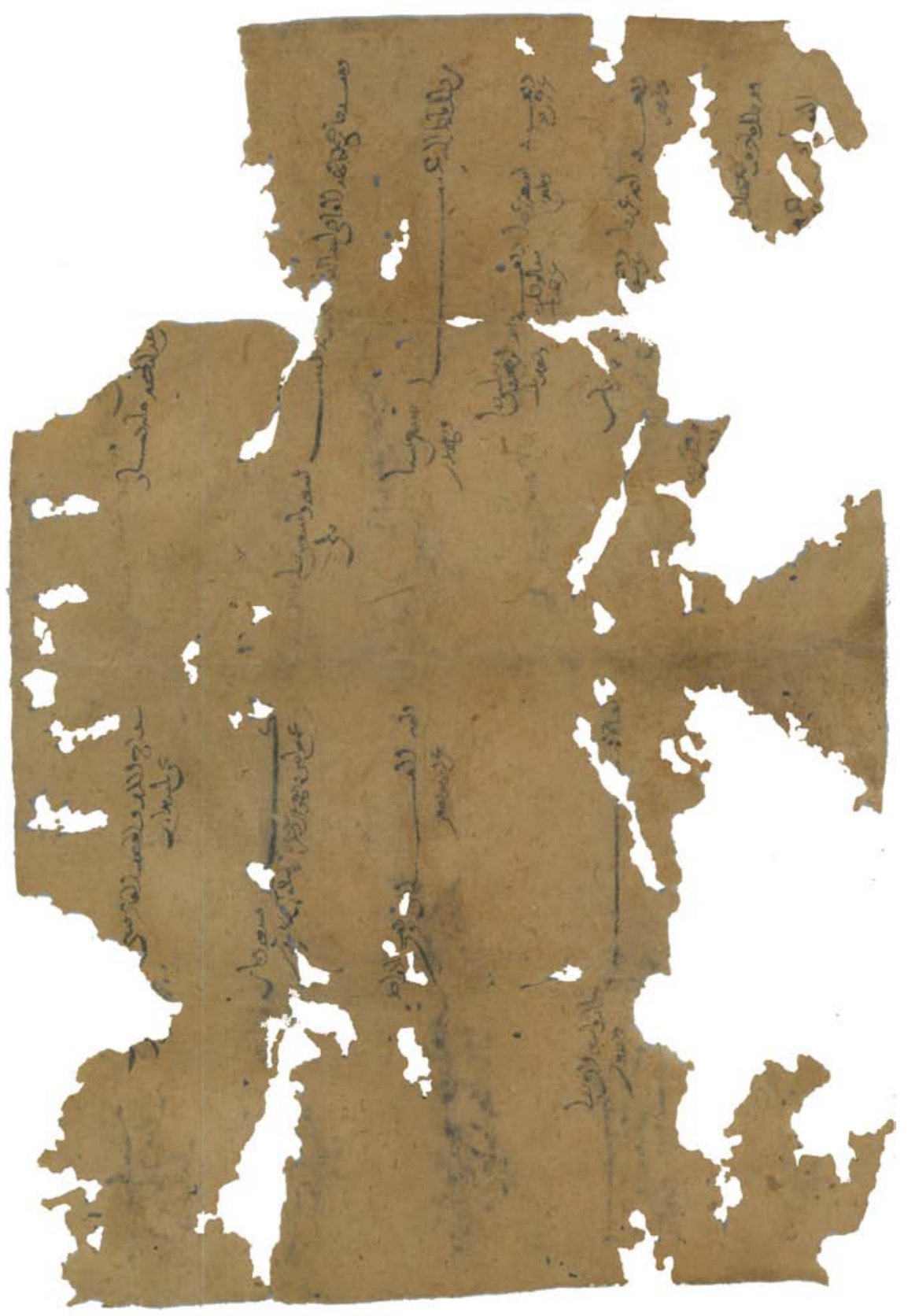

FIG. $14 \cdot 3$

P. Haun. Inv. Arab. 22 recto. Courtesy of the Papyrus Carlsberg Collection. 


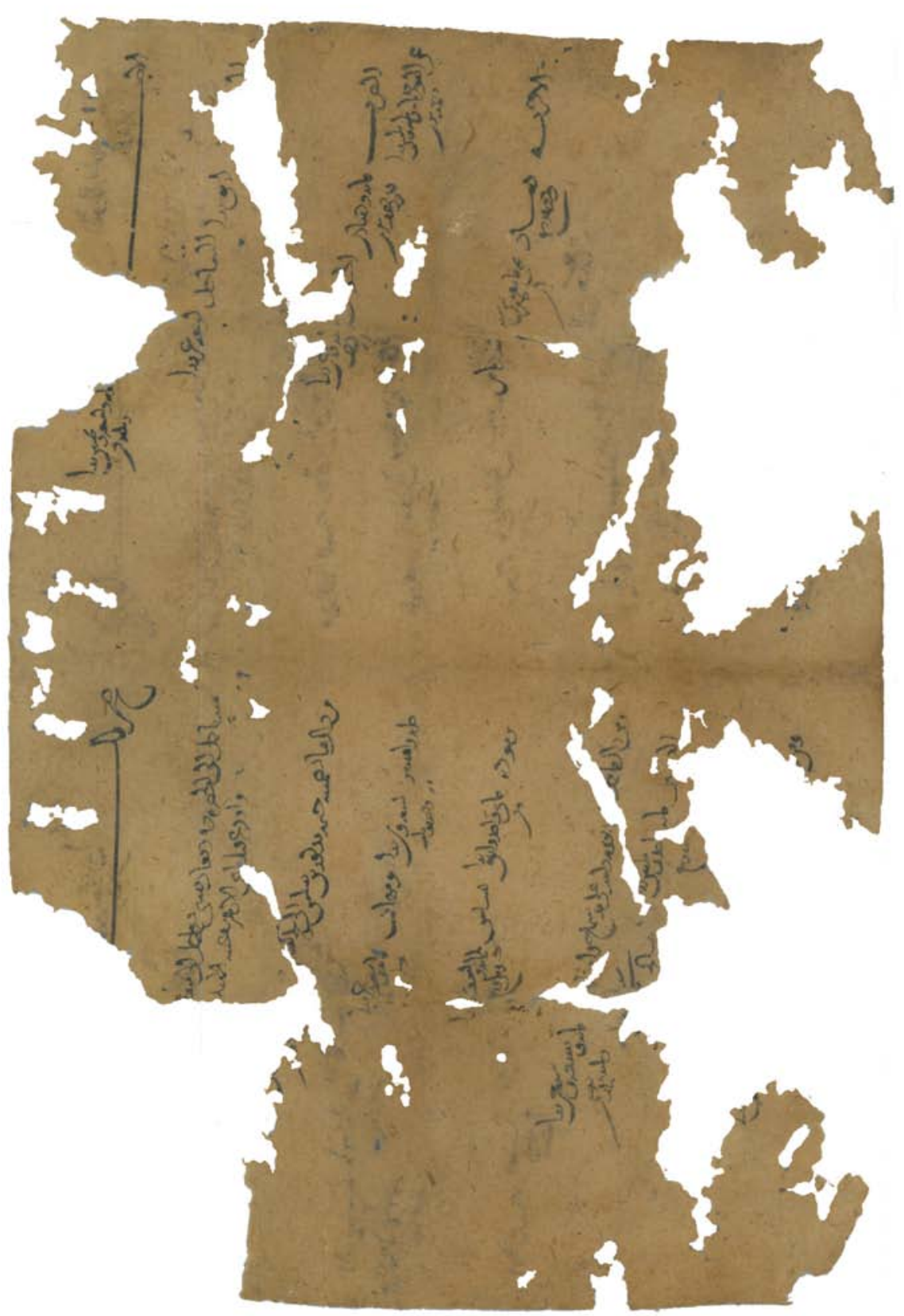

FIG. 14.4 P. Haun. Inv. Arab. 22 verso. Courtesy of the Papyrus Carlsberg Collection. 


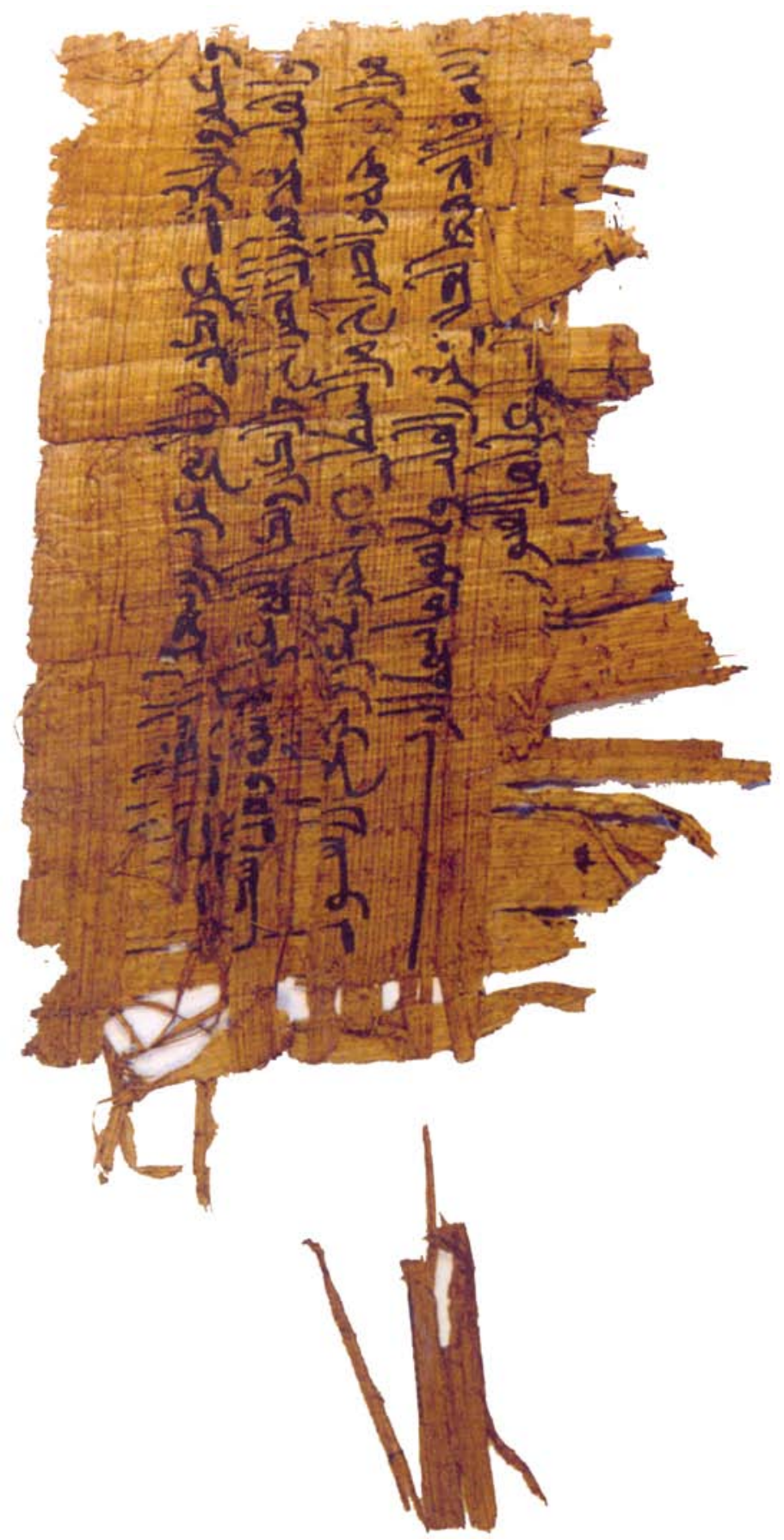

FIG. $14.5 \quad$ P. ACPSI (= P.Rag. $) 126$ recto. 


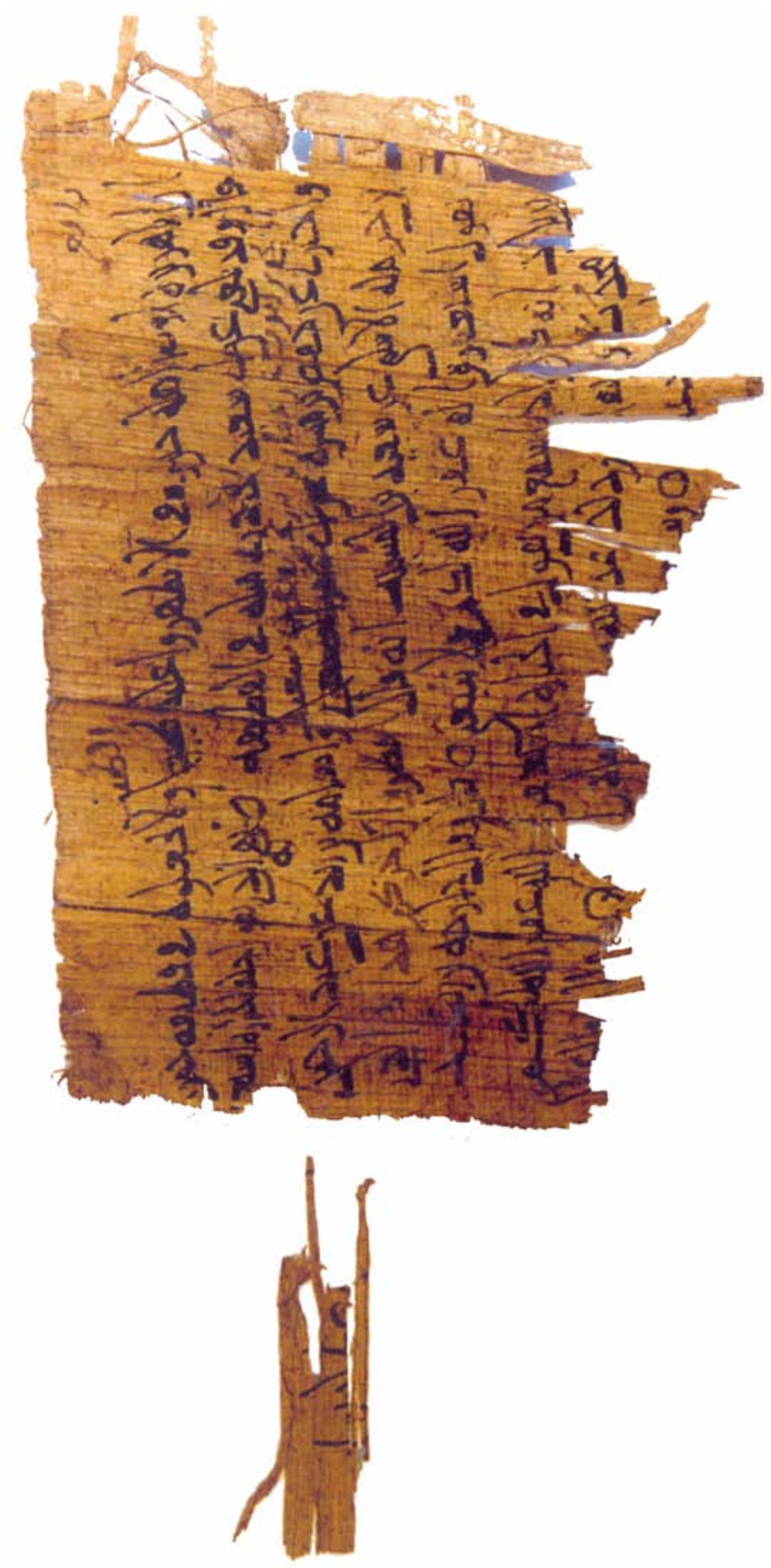

FIG. 14.6 P. ACPSI (= P.Rag. $) 126$ verso. 